\title{
Waterlogging induced oxidative stress and the mortality of the Antarctic plant, Deschampsia antarctica
}

\author{
Jeong Soo Park ${ }^{1}$ and Eun Ju Lee $2^{2^{*}}$
}

\begin{abstract}
We investigated the mortality and the oxidative damages of Deschampsia antarctica in response to waterlogging stress. In field, we compared the changes in the density of $D$. antarctica tuft at the two different sites over 3 years. The soil water content at site 2 was 6 -fold higher than that of site 1, and the density of $D$. antarctica tuft decreased significantly by $55.4 \%$ at site 2 for 3 years, but there was no significant change at site 1 . Experimental results in growth chamber showed that the $\mathrm{H}_{2} \mathrm{O}_{2}$ and malondialdehyde content increased under root-flooding treatment (hypoxic conditions - deficiency of $\mathrm{O}_{2}$ ), but any significant change was not perceptible under the shoot-flooding treatment (anoxic condition-absence of $\mathrm{O}_{2}$ ). However, total chlorophyll, soluble sugar, protein content, and phenolic compound decreased under the shoot-flooding treatment. In addition, the catalase activity increased significantly on the 1st day of flooding. These results indicate that hypoxic conditions may lead to the overproduction of reactive oxygen species, and anoxic conditions can deplete primary metabolites such as sugars and protein in the leaf tissues of D. antarctica. Under present warming trend in Antarctic Peninsula, D. antarctica tuft growing near the shoreline might more frequently experience flooding due to glacier melting and inundation of seawater, which can enhance the risk of this plant mortality.
\end{abstract}

Keywords: Waterlogging, Deschampsia antarctica, Antarctica, Flooding, Reactive oxygen species, Antioxidant enzyme activity

\section{Background}

The maritime Antarctic plant, Deschampsia antarctica Desv. (Poaceae), is one of the two angiosperms and the only monocotyledonous species naturally adapted to the harsh environmental conditions of maritime Antarctica, such as extremely high UV-B radiation, low temperatures, and high levels of salinity (Alberdi et al. 2002; Smith 2003). Previous studies have shown that $D$. antarctica has an efficient photosynthetic system in low temperature, which produces high amounts of sucrose and fructans at the end of summer (Zuñiga et al. 1996) and antioxidant substances to deal with cold and drought stresses (Bravo et al. 2001; Zamora et al. 2010). In addition, $D$. antarctica frequently experiences root or shoot flooding during its growing period because of

\footnotetext{
* Correspondence: ejlee@snu.ac.kr

${ }^{2}$ School of Biological Sciences, Seoul National University, Seoul 151-742, Republic of Korea

Full list of author information is available at the end of the article
}

snowmelt, and these stress condition can be prolonged because of global warming. However, the degree of tolerance to waterlogging stress has not yet been described.

Most plants do not have adaptive structural and metabolic features to combat anoxic/hypoxic condition, with the exception of wetland plant species (Pezeshki 2001). This lack of oxygen or anoxic condition may induce changes in the redox state of plant species and their mortality (Ricard et al. 1994; Drew 1997). Plants respond to flooding by closing their stomata to avoid water loss and subsequently downregulating the photosynthetic machinery (Ahmed et al. 2002; Yetisir et al. 2006), both of which lead to the formation of reactive oxygen species (ROS) within the leaf because of the light reaction. These ROS can cause lipid peroxidation and consequently cause membrane injury, protein degradation, enzyme inactivation, and disruption of DNA strands (Allen 1995). To cope with oxidative stress, plants produce antioxidant compounds such as ascorbate, 
glutathione, and phenolic compound as well as antioxidant enzymes, such as superoxide dismutase, ascorbate peroxidase, catalase, and glutathione reductase (Gill and Tuteja 2010).

In late January 2010, we frequently found $D$. antarctica tufts submerged under the water in Barton Peninsula because of heavy snowfall in 2009. We hypothesized that D. antarctica may experience waterlogging-induced oxidative stress and root- and shoot-flooding condition can affect this plant differently. The objectives of this study were (1) to figure out the waterlogging effect on the mortality of D. antarctica and (2) to estimate the physiological responses of $D$. antarctica under root- and shoot-flooding conditions.

\section{Methods}

Study sites and field survey

The study site is situated at Barton Peninsula, Antarctic Peninsula (site 1: $62^{\circ} 14^{\prime} 11^{\prime \prime} \mathrm{S}, 58^{\circ} 43^{\prime} 05^{\prime}$ 'W, site 2: $62^{\circ} 14^{\prime} 28^{\prime \prime} \mathrm{S}, 58^{\circ} 44^{\prime} 46^{\prime \prime} \mathrm{W}$ ) (Fig. 1). In a geomorphological aspect, site 1 was mainly covered with rocks and gravelstones, but site 2 had a higher ratio of clay in the soil than site 1 because of the seasonal stream which continuously supplies clay and snow melting water during plants growing season (Fig. 1). The mean temperature was $1.8^{\circ} \mathrm{C}$ in January and $-5.1{ }^{\circ} \mathrm{C}$ in July, and the mean $( \pm \mathrm{SD})$ annual precipitation was $566 \pm 216 \mathrm{~mm}$ during 2000-2010 (data from the nearest meteorological station, King Sejong Station; the straight-line distance between meteorological station and site 1 was $3.8 \mathrm{~km}$ ). In 2009 , precipitation $(1055 \mathrm{~mm})$ was twice as high as the 10-year average, and we found that the $D$. antarctica tufts submerged under the water at both sites from late January to early February in 2010 . A quadrat $(1 \mathrm{~m} \times 1 \mathrm{~m})$ survey was conducted in site 1 and site 2 on King George Island, where a large number of D. Antarctica tuft was found in January of 2009, 2010, and 2011. We selected 120 quadrats $(2009,2010)$ and 100 quadrats $(2011)$ per a site in a $1000-\mathrm{m}^{2}$ area and calculated the mean density of $D$. antarctica tuft. We defined a tuft as more than five shoots that were held together at ground bottom; seedlings were excluded from the count of tuft.

\section{Topographic variable and soil analysis}

Topographic variables such as elevation, aspect, slope, and distance from shoreline were derived from the digital elevation model (DEM) which has $1 \mathrm{~m}$ grid cell size. We selected 30 different points randomly within the study sites and calculated the minimum and maximum topographic values.

To document differences in soil characteristics between the two study sites, samples were collected from five random quadrats $(1 \mathrm{~m} \times 1 \mathrm{~m})$ in January 2010. Soil $\mathrm{pH}$ (soil to distilled water $=1: 5 \mathrm{w} / \mathrm{v}$ ) were measured using $\mathrm{pH}$ meter. The water content was determined after drying the samples in a $105^{\circ} \mathrm{C}$ oven for $48 \mathrm{~h}$, and organic matter content was calculated according to the weight lost after the samples were kept in a muffle furnace at $550^{\circ} \mathrm{C}$, for $4 \mathrm{~h}$ (John 2004). Total nitrogen content was determined by an element analyzer (EA1110, CE Instruments, UK) at the National Center for Inter-University Research Facilities, Seoul National University. Bray No. 1 solution (Bray and Kurtz 1945) was used to extract $\mathrm{PO}_{4}-\mathrm{P}$ for colorimetric assay by the ascorbic acid reduction method (Kovar and Pierzynski 2009). Soil texture was determined by a hydrometer analysis method (Day and Black 1965).
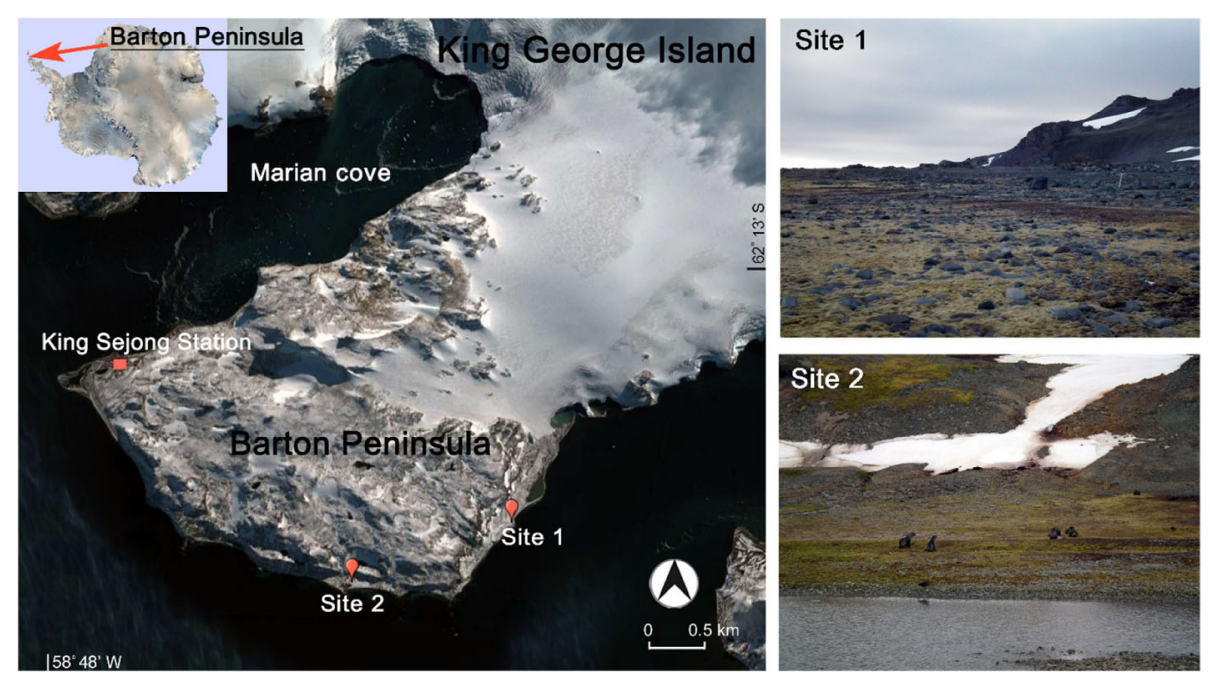

Fig. 1 The locations of site 1 and site 2 at Barton Peninsula, King George Island (left), and the pictures of two sites in January 2011 (right) 


\section{Plant material and growth conditions}

$D$. antarctica tufts were collected from both study sites. The shoot length and tuft diameter of sampled plants was approximately $8 \mathrm{~cm}$ and $4 \mathrm{~cm}$, respectively, and they had at least 10 shoots. Plant materials were cultured in the pots (diameter $12 \mathrm{~cm}$, height $14 \mathrm{~cm}$ ) with soil to peat mixture (2:1) and were watered twice a week with $0.5 \mathrm{~L}$ of a diluted Hyponex solution (Hyponex, Japan) in growth chambers (light/dark, $18 / 6$ and $22 / 20^{\circ} \mathrm{C}$; irradiance $400 \mu \mathrm{mol} \mathrm{m} \mathrm{m}^{-2} \mathrm{~s}^{-1}$ ) for 2 months. Plants were allowed to acclimatize to the conditions for 2 weeks by incubating them in a cold room with a photoperiod of $18 \mathrm{~h}$ light $/ 6 \mathrm{~h}$ dark and average temperature $( \pm \mathrm{SD})$ of $5 \pm 1{ }^{\circ} \mathrm{C}$. For the water-logging treatment, 1 group of plants (randomly selected) was subjected to continuous flooding at $2 \mathrm{~cm}$ above the soil surface (root flooding) $(n=4)$, and another group of plants was flooded above the plant surface (shoot flooding) $(n=4)$. A third group of plants was maintained under moist soil and considered as control $(n=4)$. Flooding conditions were maintained for 7 days, after which the pots were drained to permit plant recovery from the flooding. Four leaves were collected randomly in each tuft and made one sample. Only those leaves showing clear senescence symptoms were excluded. Plant tissue was immediately frozen in liquid nitrogen. The frozen material was ground to fine powder using a pre-chilled mortar and pestle stored at $-80^{\circ} \mathrm{C}$.

\section{$\mathrm{H}_{2} \mathrm{O}_{2}$ content}

To estimate the formation of reactive oxygen species in response to flooding condition, we measured the $\mathrm{H}_{2} \mathrm{O}_{2}$ content; $1 \mathrm{~g}$ of leaves was homogenized in $3 \mathrm{~mL}$ of $100 \mathrm{mM}$ sodium phosphate buffer ( $\mathrm{pH} 6.8$ ). To remove cellular debris, the homogenate was centrifuged at 18 , $000 \times g$ for $20 \mathrm{~min}$ at $4{ }^{\circ} \mathrm{C}$. The supernatant was collected to assay the $\mathrm{H}_{2} \mathrm{O}_{2}$ content. Measurement of $\mathrm{H}_{2} \mathrm{O}_{2}$ content was performed according to the modified method of Bergmeyer (1974) using a peroxidase enzyme. To initiate the enzyme reaction, a $0.5-\mathrm{mL}$ aliquot of the supernatant was mixed with $2.5 \mathrm{~mL}$ of peroxide reagent $(83 \mathrm{mM}$ sodium phosphate, $\mathrm{pH} 7.0,0.005 \%$ ( $w: v)$ o-dianisidine, and $40 \mathrm{mg}$ peroxidase per $\mathrm{mL}$ ) and incubated for $10 \mathrm{~min}$ at $30^{\circ} \mathrm{C}$ in a water bath. The reaction was stopped by adding $0.5 \mathrm{~mL}$ of $1 \mathrm{~N}$ perchloric acid and centrifuged at $5000 \times g$ for $5 \mathrm{~min}$. The resulting supernatant was read at $436 \mathrm{~nm}$, and its absorbance was compared to the extinction of an $\mathrm{H}_{2} \mathrm{O}_{2}$ standard.

\section{Malondialdehyde (MDA) content}

The MDA concentration was used to estimate oxidative damage to lipid membranes, carbohydrates, and amino acids. The MDA content was measured following the procedure described in Hodges et al. (1999). A 0.2-g aliquot of frozen plant material was homogenized in $2.5 \mathrm{~mL}$ of $80 \%$ cold ethanol using an ice-cold mortar and pestle. Homogenates were centrifuged at 15, $000 \times g$ for $10 \mathrm{~min}$ at $4{ }^{\circ} \mathrm{C}$ and the supernatant was mixed either with $20 \%$ Trichloroacetic acid (TCA) or with a mixture of $20 \% \mathrm{TCA}$ and $0.5 \%$ thiobarbituric acid (TBA). Both mixtures were allowed to react in a water bath at $95^{\circ} \mathrm{C}$ (for $30 \mathrm{~min}$, cooled, and centrifuged). Absorbance (Abs) at $440 \mathrm{~nm}, 532 \mathrm{~nm}$, and $600 \mathrm{~nm}$ was read against a blank. The MDA equivalents were calculated as follows (Hodges et al. 1999):

1) $\mathrm{A}=\left(\right.$ Abs $\left.532_{+ \text {ТВA }}\right)-\left(\right.$ Abs $\left.600_{+ \text {ТВА }}\right)-\left(\right.$ Abs $532_{-}$ ТВА - Abs 600-твА

2) $\mathrm{B}=\left(\right.$ Abs $440_{+\mathrm{TBA}}-$ Abs $\left.600_{+\mathrm{TBA}}\right) \times 0.0571$

3) $\mathrm{MDA}$ equivalents $(\mathrm{nmol} / \mathrm{mL})=((\mathrm{A}-\mathrm{B}) / 157,000) \times$ $10^{6}$

MDA equivalents were expressed as nmol MDA per gram of fresh weight.

\section{Chlorophyll, soluble sugar, and protein content}

We measure the change of the metabolite such as chlorophyll, soluble sugar, and protein when exposed to flooding. Total chlorophyll (photosynthetic pigment) was determined spectrophotometrically from extracts in $80 \%$ dimethyl sulfoxide (DMSO) using the predetermined extinction coefficients and equations (Wellburn 1994). Accurately weighed $0.2 \mathrm{~g}$ of fresh plant leaf sample was taken, and extract with $4 \mathrm{ml}$ of DMSO solvent. The contents of total chlorophyll were estimated according to experimental equations as described by Wellburn (1994).

The soluble sugar concentrations were estimated according to the method described by Marshall (1986). Determination of the amounts of soluble sugars in tissues was carried out using $0.2 \mathrm{~g}$ of homogenized plant material. Extraction of soluble sugars was carried out with $80 \%$ ethanol. After centrifugation, the soluble supernatant was collected. The entire residue that remained after the removal of soluble sugars was dried and subjected to prolonged hydrolysis with $1.1 \%$ hydrogen chloride (provides complete hydrolysis) during incubation in a water bath at $100^{\circ} \mathrm{C}$ for $30 \mathrm{~min}$. The obtained soluble sugar and hydrolyzed starch extracts were reacted separately with anthrone reagent $(0.1 \%$ anthrone in $72 \%$ sulfuric acid) to produce a blue-green color, and the absorbance was measured at $620 \mathrm{~nm}$. The concentrations of sugar were calculated using glucose curves as standards. The protein content was determined using a Bradford method, and its concentration was calculated using a calibration curve made with Bovine serum albumin (BSA) (Kruger 2009). 


\section{Phenolic compound and catalase activity}

To identify the ability of $D$. antarctica to cope with oxidative stress, we measured the antioxidant compounds (phenolic compound) and antioxidant enzymes activity (catalase). The phenolic compound content of the leaves was determined by dissolving $0.2 \mathrm{~g}$ of leaf homogenates in $2 \mathrm{~mL}$ of $95 \%$ methanol solution. The extract was then centrifuged at $15,000 \times g$ for $10 \mathrm{~min}$ at $4{ }^{\circ} \mathrm{C}$. Phenolic content was quantified using the Folin-Ciocalteu $(\mathrm{F}-\mathrm{C})$ assay (Ainsworth and Gillespie 2007). A mixture of $10 \%$ of $\mathrm{F}-\mathrm{C}$ reagent and $700 \mathrm{mM}$ sodium carbonate was added to the aliquot of the supernatant. The mixture was incubated at $30^{\circ} \mathrm{C}$ for $1 \mathrm{~h}$ and absorbance was recorded at $765 \mathrm{~nm}$. The phenolic content was calculated by comparing results with a gallic acid calibration curve.

Aliquots of $0.1 \mathrm{~g}$ of plant material were immediately frozen in liquid nitrogen and ground using a mortar and pestle. The frozen powder was mixed with $1 \mathrm{~mL}$ of 100 $\mathrm{mM}$ potassium phosphate buffer $(\mathrm{pH} 7.5)$ and centrifuged at $15,000 \times g$ for $20 \mathrm{~min}$. The supernatant was collected for enzyme analysis catalase (CAT) activity was determined as described by Azevedo et al. (1998) with some modifications. CAT activity was assayed spectrophotometrically in a reaction mixture containing $2 \mathrm{~mL}$ of $100 \mathrm{mM}$ potassium phosphate buffer ( $\mathrm{pH} 7.5$ ) with $5 \mu \mathrm{L}$ of $\mathrm{H}_{2} \mathrm{O}_{2}$ (30\% solution) prepared immediately before use. The reaction was initiated by the addition of $30 \mu \mathrm{L}$ of plant extract, and the activity was determined by following the decomposition of $\mathrm{H}_{2} \mathrm{O}_{2}$ as indicated by the changes in absorbance at $240 \mathrm{~nm}$ for 2 min against a $\mathrm{H}_{2} \mathrm{O}_{2}$-free blank.

\section{Statistical analysis}

The results are presented as means $\pm \mathrm{SE}$. For all biochemical assays, 4 samples taken from independent pots were used. One-way analysis of variance (ANOVA) and comparisons between means were made with the least significant difference (LSD) test at $p \leq 0.05$, after which the Duncan multiple-range test was applied to determine differences of the density of $D$. antarctica tuft for 3 years. Paired MannWhitney $U$ test was carried out to determine differences between before flooding (control) and flooding treatment. Statistical analyses were performed using $\mathrm{R}$ (version 3. 4. 4).

\section{Results}

\section{The density of $D$. antarctica tuft in the field}

To determine the mortality of $D$. antarctica growing in different environmental conditions (site 1 vs. site 2), the density of $D$. antarctica tuft was measured over 3 years. The density of $D$. antarctica tuft decreased significantly by $55.4 \%$ at site 2 from 2009 to 2011, but there was no significant change at site 1 (Fig. 2). Furthermore, the mean plant density at site 2 was lower than that at site 1. Two sites located near the shoreline had similar elevation and slope degree except for slope aspect. However, when we compared the soil physio-chemical properties between the two sites, all soil characteristics differed significantly, except for the total nitrogen content. In particular, the soil water content at site 2 was 6 -fold higher than that at site 1 , and the clay percent at site 2 was also 5.4-fold higher than that at site 1 (Table 1). These two soil characteristics induced soil hypoxic conditions.

\section{Changes of $\mathrm{H}_{2} \mathrm{O}_{2}$ formation and oxidative stress}

The $\mathrm{H}_{2} \mathrm{O}_{2}$ levels in the leaf tissues of $D$. antarctica significantly increased at 7 th day of root flooding $(52 \%)$ as compared to before flooding (BT). $\mathrm{H}_{2} \mathrm{O}_{2}$ levels further increased over the 2nd day of drainage in root flooding (59\%). The MDA equivalent showed a similar trend with the $\mathrm{H}_{2} \mathrm{O}_{2}$ levels when exposed to flooding. MDA equivalent increased (84\% and 123\%) at 7th day of root flooding and 2nd day of drainage, respectively. However, unchanged MDA equivalent was found in non-flooding and shoot flooding treatment (Fig. 3).

\section{Changes of chlorophyll and primary metabolites}

Figure 4 presents the effects of flooding on the chlorophyll, total soluble sugar, and protein content in the
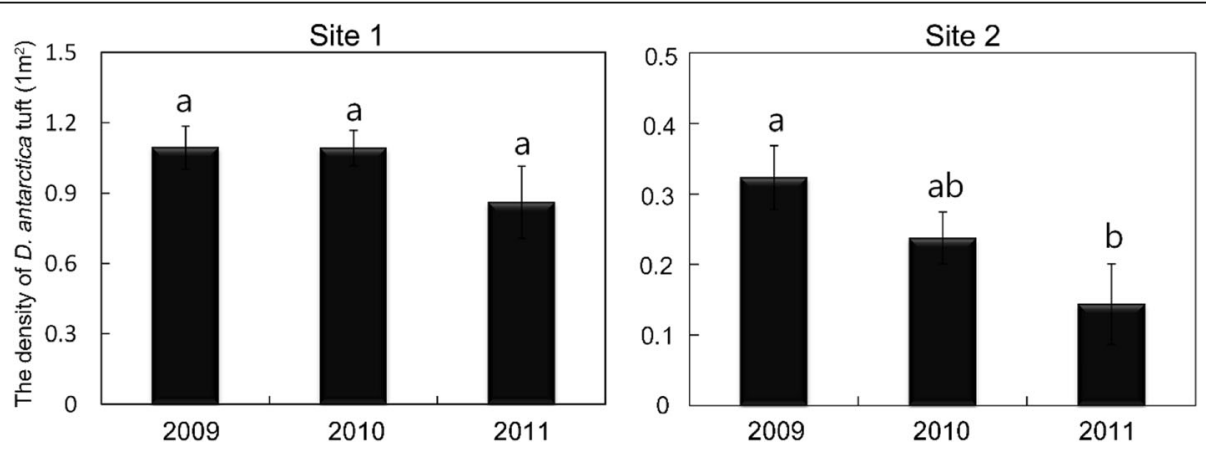

Fig. 2 The density of D. antarctica tuft at site 1 and site 2 on King George Island for 3 years (2009-2011). Values are shown as the means \pm SE of 120 quadrat replications in 2009 and 2010, and 100 quadrat replications in 2011 in a 1000- $\mathrm{m}^{2}$ area. The different letters denote statistical difference at $p \leq 0.05$ (Duncan multiple-range test) 
Table 1 Topography (minimum-maximum) and soil physiochemical properties at site 1 and site 2 on King George Island

\begin{tabular}{llll}
\hline & Variables & Site 1 & Site 2 \\
\hline Topography & Elevation $(\mathrm{m})$ & $3.2-5.3$ & $2.1-4.5$ \\
& Slope degree $\left(^{\circ}\right)$ & $2.5-5.2$ & $1.8-4.8$ \\
& Slope aspect $\left(^{\circ}\right)$ & $95-125$ & $160-210$ \\
& Distance from shoreline $(\mathrm{m})$ & $110-180$ & $55-120$ \\
Soil properties & WC (\%) & $6.9 \pm 0.5^{\mathrm{b}}$ & $41.6 \pm 4.2^{\mathrm{a}}$ \\
& OM (\%) & $3.0 \pm 0.1^{\mathrm{b}}$ & $7.1 \pm 0.5^{\mathrm{a}}$ \\
& Sand (\%) & $93.7 \pm 0.7^{\mathrm{a}}$ & $75.8 \pm 1.1^{\mathrm{b}}$ \\
& Clay (\%) & $3.5 \pm 0.4^{\mathrm{b}}$ & $19 \pm 1.2^{\mathrm{a}}$ \\
& PH & $6.0 \pm 0.03^{\mathrm{a}}$ & $5.4 \pm 0.05^{\mathrm{b}}$ \\
AP $(\mu \mathrm{g} / \mathrm{g})$ & $5.0 \pm 0.4^{\mathrm{b}}$ & $30.4 \pm 2.2^{\mathrm{a}}$ \\
T-N wt (\%) & $0.21 \pm 0.03^{\mathrm{a}}$ & $0.27 \pm 0.01^{\mathrm{a}}$ \\
\hline
\end{tabular}

Soil properties values are means \pm SE $(n=5)$. Different letters denote statistical difference at $p \leq 0.05$

WC water content, $O M$ organic matter, AP available phosphorus, $T-N$ total nitrogen

shoots of $D$. antarctica. The total chlorophyll content significantly decreased after the 1st day of shoot flooding (25\%) and 3rd day of root flooding (29\%). In particular, shoot-flooded plants showed a significant reduction in their chlorophyll content on the 1st and 3rd days of flooding in comparison with the levels before flooding and recovered their chlorophyll content 2nd day after drainage (Fig. 4a). The total soluble sugar content decreased $80 \%$ after the 3 rd day of shoot-flooding (Fig. 4b). Although the total soluble sugar content recovered to the pre-treatment level after the 2nd day of drainage, it was significantly lower than those of the non- and root-flooded plants. The protein content decreased significantly after the 7th day of shoot flooding and recovered after drainage. However, other treatments did not show any changes over the experimental period (Fig. 4c).

\section{Changes of antioxidant compound and enzyme}

The phenolic compound in the shoots of $D$. antarctica decreased significantly by $20 \%$ in root-flooding and $19 \%$ in shoot flooding after the 1st day of flooding treatment $(p \leq 0.1)$. The decreasing of phenolic content was continued until the 7th day of flooding and recovered after drainage (Fig. 5a). The decreasing trend in phenolic content experiencing shoot flooding was the same as that of root flooding. The CAT activity increased by $91 \%$ in root-flooding and $66 \%$ in shoot flooding at the 1st day of flooding treatment, and after the 3rd day of flooding, the CAT activity was not different statistically as compared to before flooding (Fig. 5b).

\section{Discussion}

Several physio-chemical analyses have been carried out to determine the responses of $D$. antarctica under drought and cold stress condition (Pérez-Torres et al. 2004; Zamora et al. 2010). However, studies of the response of the antioxidative system of $D$. antarctica under waterlogging stresses are scarce. In this study, $D$. antarctica was shown to be damaged from a prolonged soil-flooding condition. Table 1 and Fig. 2 illustrate that high soil water content and clay content could have adverse effects on the survival of $D$. antarctica during its growing season. The spatial distribution of $D$. antarctica along environmental gradients also showed that waterlogging induced by heavy snowfall can limit the survival of D. antarctica tuft and its seedling (Park et al. 2013).

In the present study, $\mathrm{H}_{2} \mathrm{O}_{2}$ and MDA levels did not change as a result of shoot flooding in anoxic conditions. However, $\mathrm{H}_{2} \mathrm{O}_{2}$ and MDA contents increased in rootflooded plants, which represent hypoxic conditions (Fig. 2). $\mathrm{H}_{2} \mathrm{O}_{2}$ accumulation under hypoxic conditions has been shown in the roots and leaves of Hordeum vulgare (Kalashnikov et al. 1994). Hypoxic tissues show over the reduction of the photosynthetic electron transport chain and mitochondria-dependent reactive oxygen
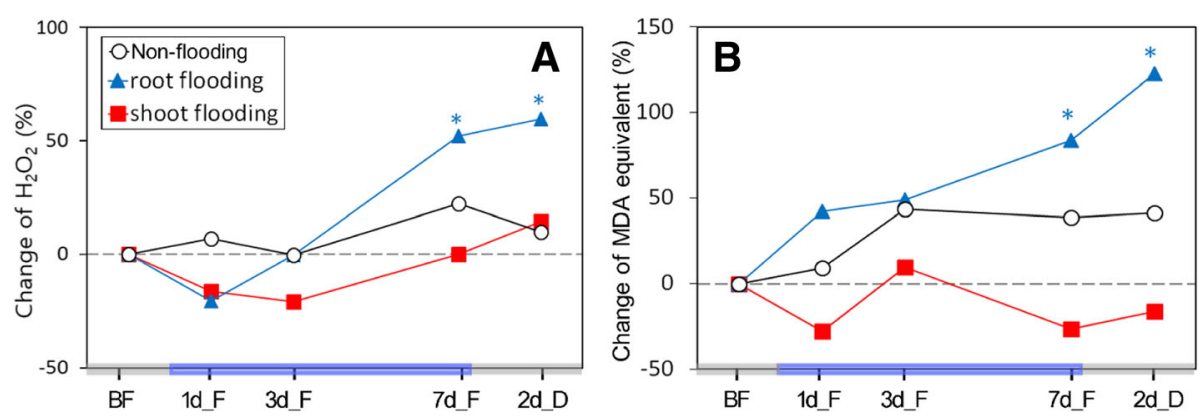

Fig. 3 Effect of flooding on $\mathrm{H}_{2} \mathrm{O}_{2}$ (a) and MDA equivalent (b) in the leaf tissues of $D$. antarctica. Graphs show changes (in percent) over a period of 7 days flooding (7d_F) and 2 days drainage (2d_D) when compared to the control (before flooding (BF)). Significant differences were calculated between control and flooding conditions with paired Mann-Whitney $U$ test; "." and "*," respectively, indicate significance at the 0.1 and 0.05 levels of confidence 

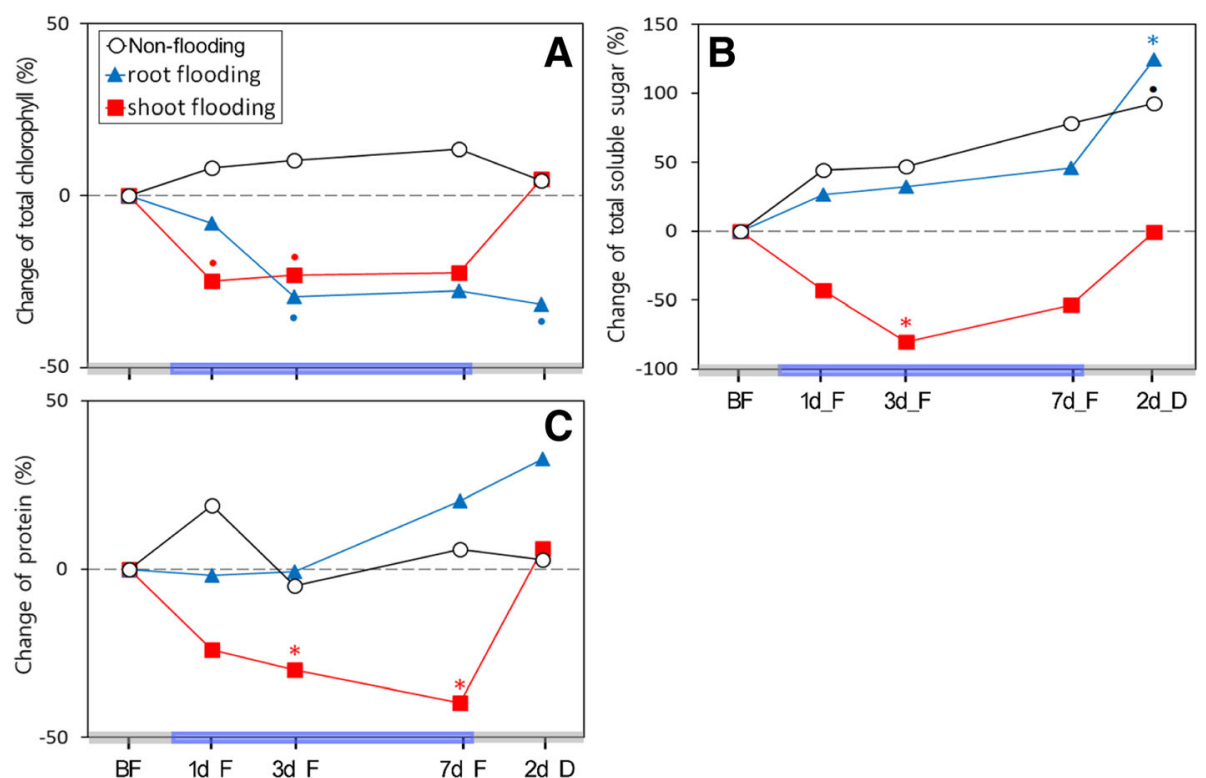

Fig 4 Effect of flooding on total chlorophyll (a), total soluble sugar (b), and protein (c) in the leaf tissues of D. antarctica. Graphs show changes (in percent) over a period of 7 days flooding (7d_F) and 2 days drainage (2d_D) when compared to the control (before flooding (BF)). Significant differences were calculated between control and flooding conditions with the paired Mann-Whitney $U$ test; "." and "*," respectively, indicate significance at the 0.1 and 0.05 levels of confidence

species (ROS) generation, which results in oxidative damage to cellular components such as lipids, proteins, sugars, and nucleic acids (Sairam et al. 2008). In contrast, the reduction of ROS production in anoxic conditions could be due to a shift from aerobic respiration to fermentation, which leads to reduced ROS production in mitochondrial sites (Sairam et al. 2009). This may also have retarded the production of chemical energy provided by light reaction systems, which are thought to be used for the production of ROS under stressful condition (Ahmed et al. 2002). These results suggest that $D$. antarctica in a hypoxic state could suffer more oxidative stress than those in anoxic conditions, and oxygen deprivation stress could induce harmful effects on the cellular components of these plants.

A reduction in chlorophyll content was reported after several days of flooding in wheat (Collaku 2002). We found that total chlorophyll content in D. antarctica also decreased in flooding conditions (Fig. 4a), which may contribute to the blockage in the photosynthetic site of chemical energy and ROS production. Furthermore, our results show that total soluble sugar (Fig. 4b), which is a typical product of the photosynthetic reaction, was significantly decreased in shoot flooding treatment. The
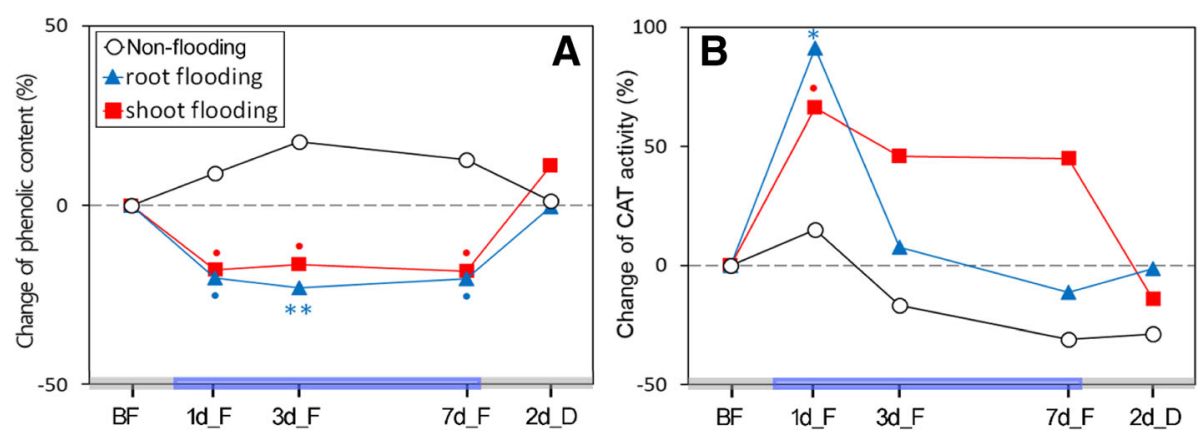

Fig. 5 Effect of flooding on phenolic content (a) and CAT activity (b) in the leaf tissues of D. antarctica. Graphs show changes (in percent) in five parameters over a period of 7 days flooding (7d_F) and 2 days drainage (2d_D) when compared to the control (before flooding (BF)). Significant differences were calculated between control and flooding conditions with the paired Mann-Whitney $U$ test; "*," "**" and "**", respectively, indicate significance at the $0.1,0.05$, and 0.01 levels of confidence 
previous study reported that photosynthetic capacity has significantly inhibited in flooding-intolerant plants when exposed to anoxia (Liao and Lin 2001).

High accumulation of soluble sugar could be one of the protective mechanisms against low temperature in maritime Antarctica (Zuñiga et al. 1996). Therefore, lower soluble sugar contents attributed to flooding stress could be lethal to $D$. antarctica in the Antarctic area. Furthermore, a decrease in protein content indicates serious damage in the metabolic rate of $D$. antarctica.

While phenolic content was increased under drought stress in D. antarctica (Zamora et al. 2010), its content decreased in the case of flooding stress (Fig. 5b). Most phenolic compounds are very effective scavengers of hydroxyl and peroxyl radicals and can stabilize lipid peroxidation (Yamasaki et al. 1997). CAT activity showed higher levels initially, but then declined quickly in plants that experienced root flooding. Ahmed et al. (2002) also reported the same antioxidant enzyme response in waterlogging stressed mung beans. This result may indicate a cellular protective mechanism to mitigate damage in earlier stressed conditions, but with the progression of oxygen deprivation, the enzyme activity decreased dramatically.

\section{Conclusions}

The mortality of D. antarctica and the changes of $\mathrm{H}_{2} \mathrm{O}_{2}$ and MDA contents under waterlogging condition demonstrate that $D$. antarctica is sensitive to root flooding condition. Furthermore, these results showed that $D$. antarctica prefers well-drained soil to poorly drained soil. Although increasing antioxidant enzymes showed that this plant can overcome the hypoxic stress for a short period of time, $\mathrm{H}_{2} \mathrm{O}_{2}$ and MDA contents were steadily increased during the root-flooding (hypoxia) treatment period. Under shoot-flooding (anoxia) conditions, ROS production was not increased significantly because oxidative phosphorylation of mitochondria was replaced with anaerobic fermentation (Davies 1980). Soluble sugar and protein content were more significantly dropped after the onset of anoxic treatment than hypoxic treatment. These results suggest that photosynthesis and the activities of the enzyme-related nitrate reduction and ammonia assimilation may be inhibited more severely during anoxic condition than hypoxic condition (Hsu et al. 1999; Liao and Lin 1996). These responses under flooding conditions could be detrimental to the survival of $D$. antarctica in the harsh environmental conditions of maritime Antarctica. We can predict that the soil water flooding induced by recent accelerated ice melting in this region may affect the mortality and the distribution of D. antarctica. Especially, over the last 50 years, the Antarctic Peninsula has experienced rapid warming than in the rest of Antarctica and the ice shelves around the Antarctic Peninsula have retreated remarkably (Vaughan et al. 2003). Specifically, Lee et al. (2008) predicted that the glacier in Marian cove near the study sites may disappear by 2060 under the present warming trend. $D$. antarctica tuft growing at the shoreline area might more frequently experience flooding due to glacier melting and inundation of seawater, which can enhance the risk of this plant mortality.

\section{Abbreviations}

ANOVA: Analysis of variance; AP: Available phosphorus; BSA: Bovine serum albumin; CAT: Catalase; DEM: Digital elevation model; DMSO: Dimethyl sulfoxide; F-C: Folin-Ciocalteu; LSD: Least significant difference; MDA: Malondialdehyde; OM: Organic matter; ROS: Reactive oxygen species; TBA: Thiobarbituric acid; TCA: Trichloroacetic acid; T-N: Total nitrogen; WC: Water content

\section{Acknowledgements}

We are very grateful to all the staff of the King Sejong Station for their cooperation and hospitality.

\section{Authors' contributions}

JSP participated in the design of the study, field survey, and data analysis and wrote the manuscript draft. EJL participated in the design of this study and edited the manuscript. Both authors read and approved the final manuscript.

\section{Funding}

This research was supported by the Korea Polar Research Institute grant "Status and Changes of Polar Indicator Species and Coastal/Terrestrial Ecosystems (PE10040)" and by National Institute of Ecology grant "Ecological Studies of Alien Species (NIE-A-2019-08)."

Ethics approval and consent to participate

Not applicable

\section{Consent for publication}

Not applicable

\section{Competing interests}

The authors declare that they have no competing interests.

\section{Author details}

${ }^{1}$ Alien Species Research Team, National Institute of Ecology, Seocheon-gun, Chungcheongnam-do 33657, Republic of Korea. ${ }^{2}$ School of Biological Sciences, Seoul National University, Seoul 151-742, Republic of Korea.

Received: 11 June 2019 Accepted: 17 July 2019

Published online: 30 July 2019

\section{References}

Ahmed S, Nawata E, Hosokawa M, Domae Y, Sakuratani T. Alterations in photosynthesis and some antioxidant enzymatic activities of mungbean subjected to waterlogging. Plant Sci. 2002;163(1):117-23.

Ainsworth EA, Gillespie KM. Estimation of total phenolic content and other oxidation substrates in plant tissues using Folin-Ciocalteu reagent. Nature protocols. 2007;2(4):875

Alberdi M, Bravo LA, Gutierrez A, Gidekel M, Corcuera LJ. Ecophysiology of Antarctic vascular plants. Physiol. Plant. 2002;115(4):479-86.

Allen RD. Dissection of oxidative stress tolerance using transgenic plants. Plant Physiol. 1995;107(4):1049.

Azevedo R, Alas R, Smith R, Lea P. Response of antioxidant enzymes to transfer from elevated carbon dioxide to air and ozone fumigation, in the leaves and roots of wild type and a catalase deficient mutant of barley. Physiol. Plant. 1998;104(2):280-92.

Bergmeyer HU. Methods of enzymatic analysis. Weinheim: Verlag Chemie; 1974. Bravo LA, Ulloa N, Zuñiga GE, Casanova A, Corcuera LJ, Alberdi M. Cold resistance in Antarctic angiosperms. Physiol Plant. 2001;111(1):55-65. 
Bray $\mathrm{RH}$, Kurtz L. Determination of total, organic, and available forms of phosphorus in soils. Soil Sci. 1945;59(1):39-46.

Collaku AH. Losses in wheat due to waterlogging. Crop Sci. 2002;42(2):444-50.

Davies DD. Anaerobic metabolism and the production of organic acids. In: Davies DD, editor. The Biochemistry of Plants, Vol. 2. New York: Academic Press; 1980

Day PR, Particle fractionation and particle-size analysis. In Black, C. A. (ed.), Methods of soil analysis. Part 1. Physical and Mineralogical Properties, Including Statistics of Measurement and Sampling. ASA, SSSA, 1965;9: 545-567.

Drew MC. Oxygen deficiency and root metabolism: injury and acclimation under hypoxia and anoxia. Ann Rev Plant Biol. 1997:48(1):223-50.

Gill SS, Tuteja N. Reactive oxygen species and antioxidant machinery in abiotic stress tolerance in crop plants. Plant Physiol. Biochem. 2010:48(12):909-30.

Hodges DM, Delong JM, Forney CF, Prange RK. Improving the thiobarbituric acidreactive-substances assay for estimating lipid peroxidation in plant tissues containing anthocyanin and other interfering compounds. Planta. 1999;207(4):604-11.

Hsu YM, Tseng MJ, Lin CH. The fluctuation of carbohydrates and nitrogen compounds in flooded wax-apple trees. Bot Bull Acad Sin. 1999;40:193-8.

John B. A comparison of two methods for estimating the organic matter content of sediments. J Paleolimnol. 2004;31:125-7.

Kalashnikov J, Balakhnina T, Zakrzhevsky D. Effect of soil hypoxia on activation of oxygen and the system of protection from oxidative destruction in roots and leaves of Hordeum vulgare. Russ J Plant Physiol. 1994;41:583-8.

Kovar $J$, Pierzynski GM. Methods of phosphorus analysis for soils, sediments, residuals, and waters. Southern cooperative series bulletin No. 408. (Second Ed.); 2009.

Kruger NJ. The Bradford method for protein quantitation. In: The protein protocols handbook. Totowa: Humana Press; 2009.

Lee J, Jin YK, Hong JK, Yoo HJ, Shon H. Simulation of a tidewater glacier evolution in Marian Cove, King George Island, Antarctica. Geosci J. 2008;12(1):33-9.

Liao CT, Lin CH. Photosynthetic responses of grafted bitter melon seedlings to flooding stress. Environ Exp Bot. 1996:36:167-72.

Liao CT, Lin CH. Physiological adaptation of crop plants to flooding stress. Proceedings of the National Science Council, Republic of China. Part B Life Sci. 2001;25(3):148-57.

Marshall J. Drought and shade interact to cause fine-root mortality in Douglas-fir seedlings. Plant Soil. 1986;91(1):51-60.

Park JS, Ahn IY, Lee EJ. Spatial distribution patterns of the Antarctic Hair grass Deschampsia antarctica in relation to environmental variables on Barton Peninsula, King George Island. Arct Antarct Alp Res. 2013;45(4):563-74.

Pérez-Torres E, García A, Dinamarca J, Alberdi M, Gutiérrez A, Gidekel M, Ivanov AG, NPA H, Corcuera L, Bravo LA. The role of photochemical quenching and antioxidants in photoprotection of Deschampsia antarctica. Funct Plant Biol. 2004;31(7):731-41.

Pezeshki SR. Wetland plant responses to soil flooding. Environ Exp Bot. 2001:46(3):299-312

Ricard B, Couee I, Raymond P, Saglio P, Saint-Ges V, Pradet A. Plant metabolism under hypoxia and anoxia. Plant Physiol Biochem. 1994;32:1):1-10.

Sairam R, Kumutha D, Ezhilmathi K, Chinnusamy V, Meena R. Waterlogging induced oxidative stress and antioxidant enzyme activities in pigeon pea. Biol Plant. 2009;53(3):493-504

Sairam R, Kumutha D, Ezhilmathi K, Deshmukh P, Srivastava G. Physiology and biochemistry of waterlogging tolerance in plants. Biol Plant. 2008; 52(3):401-12

Smith R. The enigma of Colobanthus quitensis and Deschampsia antarctica in Antarctica. Antarctic biology in a global context. Leiden: Backhuys Publishers; 2003.

Vaughan DG, Marshall GJ, Connolley WM, Parkinson C, Mulvaney R, Hodgson DA, King JC, Pudsey CJ, Turner J. Recent rapid regional climate warming on the Antarctic Peninsula. Clim Change. 2003;60(3):243-74

Wellburn AR. The spectral determination of chlorophylls a and b, as well as total carotenoids, using various solvents with spectrophotometers of different resolution. J Plant Physiol. 1994;144(3):307-13.

Yamasaki $\mathrm{H}$, Sakihama Y, Ikehara N. Flavonoid-peroxidase reaction as a detoxification mechanism of plant cells against $\mathrm{H}_{2} \mathrm{O}_{2}$. Plant Physiol. 1997; 115(4):1405-12

Yetisir H, Caliskan ME, Soylu S, Sakar M. Some physiological and growth responses of watermelon [Citrullus lanatus (Thunb.) Matsum. and Nakai] grafted onto Lagenaria siceraria to flooding. Environ Exp Bot. 2006:58:1-8.
Zamora P, Rasmussen S, Pardo A, Prieto H, Zuniga GE. Antioxidant responses of in vitro shoots of Deschampsia antarctica to Polyethylene glycol treatment. Antarct Sci. 2010;22(2):163-9.

Zuñiga GE, Alberdi M, Corcuera LJ. Non-structural carbohydrates in Deschampsia antarctica desv. from South Shetland Islands, maritime antarctic. Environ Exp Bot. 1996;36(4):393-9.

\section{Publisher's Note}

Springer Nature remains neutral with regard to jurisdictional claims in published maps and institutional affiliations.
Ready to submit your research? Choose BMC and benefit from:

- fast, convenient online submission

- thorough peer review by experienced researchers in your field

- rapid publication on acceptance

- support for research data, including large and complex data types

- gold Open Access which fosters wider collaboration and increased citations

- maximum visibility for your research: over $100 \mathrm{M}$ website views per year

At BMC, research is always in progress.

Learn more biomedcentral.com/submissions 